\title{
Lack of Efficacy of High-Titered Immunoglobulin in Patients with West Nile Virus Central Nervous System Disease
}

\author{
John W. Gnann, Jr., Amy Agrawal, John Hart, Martha Buitrago, Paul Carson, Diane Hanfelt-Goade, \\ Ken Tyler, Jared Spotkov, Alison Freifeld, Thomas Moore, Jorge Reyno, Henry Masur, \\ Penelope Jester, Ilet Dale, Yufeng Li, Inmaculada Aban, Fred D. Lakeman, Richard J. Whitley, \\ for the National Institute of Allergy and Infectious Diseases Collaborative Antiviral Study Group
}

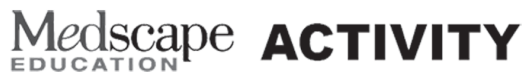

In support of improving patient care, this activity has been planned and implemented by Medscape, LLC and Emerging Infectious Diseases. Medscape, LLC is jointly accredited by the Accreditation Council for Continuing Medical Education (ACCME), the Accreditation Council for Pharmacy Education (ACPE), and the American Nurses Credentialing Center (ANCC), to provide continuing education for the healthcare team.

Medscape, LLC designates this Journal-based CME activity for a maximum of 1.00 AMA PRA Category 1 Credit(s) ${ }^{\mathrm{TM}}$. Physicians should claim only the credit commensurate with the extent of their participation in the activity.

Successful completion of this CME activity, which includes participation in the evaluation component, enables the participant to earn up to $1.0 \mathrm{MOC}$ points in the American Board of Internal Medicine's (ABIM) Maintenance of Certification (MOC) program. Participants will earn MOC points equivalent to the amount of CME credits claimed for the activity. It is the CME activity provider's responsibility to submit participant completion information to ACCME for the purpose of granting ABIM MOC credit.

All other clinicians completing this activity will be issued a certificate of participation. To participate in this journal CME activity: (1) review the learning objectives and author disclosures; (2) study the education content; (3) take the post-test with a $75 \%$ minimum passing score and complete the evaluation at http://www.medscape.org/journal/eid; and (4) view/print certificate. For CME questions, see page 2165 .

Release date: October 15, 2019; Expiration date: October 15, 2020

Learning Objectives

Upon completion of this activity, participants will be able to:

- Describe safety and tolerability of Omr-IgG-am compared with that of intravenous immunoglobulin (IVIG) and normal saline (NS) in patients with West Nile virus (WNV) neuroinvasive disease in a phase 2, randomized, double-blind, multicenter study

- Determine efficacy of Omr-IgG-am compared with that of IVIG and NS in patients with WNV neuroinvasive disease in a phase 2, randomized, double-blind, multicenter study

- Identify clinical implications of safety and efficacy of Omr-IgG-am compared with that of IVIG and NS in patients with WNV neuroinvasive disease in a phase 2 , randomized, double-blind, multicenter study.

\section{CME Editor}

Deborah Wenger, MBA, Copyeditor, Emerging Infectious Diseases. Disclosure: Deborah Wenger, MBA, has disclosed no relevant financial relationships.

\section{CME Author}

Laurie Barclay, MD, freelance writer and reviewer, Medscape, LLC. Disclosure: Laurie Barclay, MD, has disclosed no relevant financial relationships.

\section{Authors}

Disclosures: John W. Gnann Jr, MD; Amy Guillet Agrawal, MD; John Hart Jr, MD; Martha Buitrago, MD; Paul J. Carson, MD; Diane Hanfelt-Goade, MD; Kenneth L. Tyler, MD; Jared M. Spotkov, MD; Thomas A. Moore, MD; Jorge Reyno, MD, MHA; Henry Masur, MD; Penelope M. Jester, MPH; Ilet Dale, MScM, CCRP; Yufeng Li, PhD; and Fred Lakeman, PhD, have disclosed no relevant financial relationships. Alison Freifeld, $M$ D, has disclosed the following relevant financial relationships: served as an advisor or consultant for Merck \& Co., Inc.; Siemens AG; received grants for clinical research from Merck \& Co., Inc. Inmaculada B.Aban, $P h D$, has disclosed the following relevant financial relationships: received grants for clinical research from Alexion Pharmaceuticals, Inc.; Argenx US Inc.; Catalyst Pharmaceutical Partners, Inc.; Ra Pharmaceuticals, Inc. Richard Whitley, MD, has disclosed the following relevant financial relationships: served as an advisor or consultant for: GlaxoSmithKline; Merck \& Co., Inc.; resTORbio, Inc.; Sanofi; owns stock, stock options, or bonds from: Gilead Sciences, Inc. 
West Nile Virus (WNV) can result in clinically severe neurologic disease. There is no treatment for WNV infection, but administration of anti-WNV polyclonal human antibody has demonstrated efficacy in animal models. We compared Omr-lgG-am, an immunoglobulin product with high titers of anti-WNV antibody, with intravenous immunoglobulin (IVIG) and normal saline to assess safety and efficacy in patients with WNV neuroinvasive disease as part of a phase I/II, randomized, double-blind, multicenter study in North America. During 2003-2006, a total of 62 hospitalized patients were randomized to receive Omr-lgG-am, standard IVIG, or normal saline (3:1:1). The primary endpoint was medication safety. Secondary endpoints were morbidity and mortality, measured using 4 standardized assessments of cognitive and functional status. The death rate in the study population was $12.9 \%$. No significant differences were found between groups receiving Omr-lgGam compared with IVIG or saline for either the safety or efficacy endpoints.

$\mathrm{W}$ est Nile virus (WNV) is a mosquitoborne flavivirus that causes a spectrum of human illnesses, ranging from asymptomatic infection to an undifferentiated febrile syndrome (West Nile fever) and potentially lethal neuroinvasive diseases, including encephalitis and myelitis (1-5). Since its appearance in New York, USA, in 1999, WNV has become a seasonal endemic infection across North America (5-7). During 1999-2017, a total of 48,183 cases of WNV infection were reported to the Centers for Disease Control and Prevention (CDC), of which 22,999 were defined as neuroinvasive disease (8). Among patients with neuroinvasive disease, the mortality rate is $8 \%-12 \%$ $(5,8,9)$. The number of reported cases of WNV disease in the United States averaged $\approx 2,200$ cases annually during 2013-2017, although the true incidence is certainly much higher $(8,10,11)$. Currently, no vaccine or drug has been

Author affiliations: University of Alabama at Birmingham, Birmingham, Alabama, USA (J.W. Gnann, Jr., P. Jester, I. Dale, Y. Li, I. Aban, F.D. Lakeman, R.J. Whitley); National Institutes of Health Clinical Center, Bethesda, Maryland, USA (A. Agrawal, H. Masur); University of Arkansas for Medical Sciences, Little Rock, Arkansas, USA (J. Hart); Idaho Falls Infectious Diseases PLLC, Idaho Falls, Idaho, USA (M. Buitrago); North Dakota State University, Fargo, North Dakota, USA (P. Carson); University of New Mexico, Albuquerque, New Mexico, USA (D. Hanfelt-Goade); University of Colorado at Denver Anschutz Medical Campus, Aurora, Colorado, USA (K. Tyler); Kaiser Permanente South Bay Medical Center, Harbor City, California, USA (J. Spotkov); University of Nebraska Medical Center, Omaha, Nebraska, USA (D. Freifeld); Via Christi Hospital St. Francis, Wichita, Kansas, USA (T. Moore); Infectious Diseases Consultations, Rapid City, South Dakota, USA (J. Reyno)

DOI: https://doi.org/10.3201/eid2511.190537 approved by the Food and Drug Administration for prevention or treatment of human WNV infection.

The National Institute of Allergy and Infectious Diseases Collaborative Antiviral Study Group initiated a clinical trial of immunotherapy for patients with WNV encephalitis or myelitis using Omr-IgG-am (OMRIX Biopharmaceuticals, Tel Aviv, Israel), an immunoglobulin product that contains high titers of WNV IgG. Murine model experiments demonstrated that anti-WNV globulin administered near the time of infection was highly effective at preventing disease and death (12). Anecdotal cases of successful treatment of human WNV with passive immunotherapy have been reported (13-16). We conducted this phase I/II study to assess the safety and potential efficacy of Omr-IgG-am for treatment for hospitalized adults with WNV neuroinvasive disease.

\section{Methods}

\section{Design}

During 2003-2006, we enrolled patients into a prospective, randomized, double-blind, placebo-controlled trial of Omr-IgG-am, a human immunoglobulin preparation that had a WNV plaque-reduction neutralization titer of 1:200. We compared Omr-IgG-am with 2 controls: standard intravenous (IV) immunoglobulin (IVIG) (Polygam S/D; Baxter, https://www.baxter.com), derived from US sources and containing no detectable WNV IgG; and normal saline (NS) for IV administration. One hundred patients meeting entry criteria were to be randomized in a 3:1:1 ratio (60 for Omr-IgG-am, 20 for Polygam, and 20 for NS) in blocks of 5. Randomization was implemented with a web-based system developed and maintained by the Data Coordinating Center at the University of Alabama at Birmingham (Birmingham, AL, USA). Randomized patients received a single intravenous dose of study medication on day 1. Patients were followed for 90 days after dosing. All investigators and patients remained blinded for the duration of the study.

The 2 active dosage cohorts $(0.5 \mathrm{~g} / \mathrm{kg}$ and $1.0 \mathrm{~g} / \mathrm{kg}$ of Omr-IgG-am) were to accrue sequentially. However, because of slow enrollment, impending expiration of OmrIgG-am stock, and difficulty locating supplies of Polygam free of WNV IgG, the protocol was amended in 2006 to allow continued enrollment in the $0.5 \mathrm{~g} / \mathrm{kg}$ cohort and to forgo the planned $1.0 \mathrm{~g} / \mathrm{kg}$ cohort.

\section{Endpoints}

The primary endpoint was safety and tolerability of the study medications at day 90 postenrollment. The safety endpoint was defined by the number of serious adverse events (SAEs), regardless of relationship to study drug. The estimated efficacy of Omr-IgG-am in reducing illness and death among patients with confirmed WNV disease (a 
secondary endpoint) was defined by a functional score (on day 90 after randomization) based on the results of 4 standardized assessments of cognitive and functional status: the Barthel Index (BI), the Modified Rankin Scale (MRS), the Glasgow Outcome Score (GOS), and the Modified Mini Mental State Examination (3MS) (17-19). We compared outcomes for the patients receiving Omr-IgG-am and those who received control interventions. Other secondary endpoints included the proportion of patients in each group returning to preillness baseline function as assessed by the $\mathrm{BI}$ and MRS, and each patient's improvement at 3 months compared with the patient's worst prior evaluation.

\section{Study Population}

Participants were enrolled while hospitalized at community or academic medical centers; follow-up visits occurred at outpatient clinics. Two categories of participants were enrolled. The first included hospitalized patients $\geq 18$ years of age with new-onset ( $\leq 4$ days' duration) encephalitis (altered level of consciousness, dysarthria, or dysphagia), myelitis (asymmetric extremity weakness without sensory abnormality), or both. In addition, the cerebrospinal fluid (CSF) analyses (performed within the previous 96 hours) were required to show pleocytosis $\left(\geq 4\right.$ leukocytes $\left./ \mathrm{mm}^{3}\right)$ and negative tests for other pathogens. The second eligibility category included adults who were hospitalized without encephalitis or myelitis but who had positive WNV IgM or PCR results, as well as clinical findings compatible with WNV infection and a risk factor for the development of WNV neurologic disease $(\geq 40$ years of age or immunocompromised patient $\geq 18$ years of age). Confirmation of acute WNV infection by positive WNV IgM serologic results or PCR detection of WNV RNA in blood or CSF was required for inclusion in the efficacy analyses (20-22).

\section{Study Procedures}

After verifying inclusion and exclusion criteria and obtaining informed consent, patients were randomized to 1 of the 3 treatment arms. Medical history and physical examination were recorded. Detailed neurologic examinations were conducted (BI, MRS, the GOS, and the 3MS), along with an evaluation of pre-illness functional status.

We obtained CSF samples for WNV serologic testing and PCR before starting the study and performed brain magnetic resonance imaging (MRI) studies before the study and on day 30 . We examined participants on days $1-7,14,30$, and 90 . We obtained blood samples for safety laboratory studies (including complete blood count, hemoglobin A1c, platelet count, blood urea nitrogen, creatinine, creatinine phosphokinase, liver enzymes, international normalized ratio, glucose, electrolytes, amylase, and lipase); WNV, HIV, HBV, and parvovirus B19 serologic testing; and PCR for WNV, HIV, HBV, HCV, and parvovirus B19.
The unblinded research pharmacist calculated the volume of study medication. Bottles of study medication and tubing were covered with opaque plastic covers to maintain blinding. We infused study medication intravenously using a $15-\mu$ filter at an initial rate of $0.0083 \mathrm{~mL} / \mathrm{kg} / \mathrm{min}$, gradually increased to a maximum rate of $3 \mathrm{~mL} / \mathrm{min}$.

\section{Site Monitoring and Regulatory Oversight}

A total of 71 sites in the United States and Canada completed regulatory requirements for enrollment (although the list of active sites varied from year to year); participants were successfully enrolled at 24 sites. The clinical trial was conducted in accordance with the ethical standards of the Helsinki Declaration. The protocol required approval by a local institutional review board (IRB) or ethics committee before enrollment could proceed; we obtained written informed consent from each participant or a legal guardian. All sites were independently monitored at selected time points and at the completion of the study. A data and safety monitoring board oversaw the study.

\section{Statistical Analyses}

We performed statistical analyses using SAS 9.1 software (https://www.sas.com) and StaXact 4.0 (https://www.cytel. com/software/statxact) for exact statistical methods. We analyzed data using standard descriptive statistics and used Fisher's exact test to explore associations for categorical variables between the treatment arm and the 2 control arms. Nonparametric statistical methods used a Wilcoxon test for comparison of continuous variables between the treatment arm and the 2 control arms. No interim analyses were planned.

\section{Sample Size Determinations}

Because the study was a phase I/II safety study with a primary objective of estimating the rate of serious adverse events, we did not plan formal tests of hypotheses. Thus, we did not determine the sample size by power analysis. A total sample size of 100 participants was planned (60 OmrIgG-am, 20 Polygam, and $20 \mathrm{NS}$ ). With the assumption that the true adverse event rate was no more than $30 \%$, the 2 -sided $95 \%$ CIs of the estimated SAE rates were expected to be $18.4 \%-41.6 \%$ for Omr-IgG-am and $9.9 \%-50.1 \%$ for the 2 control arms.

\section{Data Analyses}

We included all 62 randomized participants in the safety analysis (intent-to-treat) and calculated estimates of adverse event rates with 2 -sided exact $95 \%$ CIs for each treatment arm. We performed efficacy analyses on 55 study participants with confirmed WNV infection, although this phase I/II safety study was not sufficiently powered to detect small-to moderate differences in outcome among the 
treatment groups. The efficacy endpoint was a combination of illness and death as defined by a functional score calculated 90 days after randomization. The endpoint was based on the results of the BI, GOS, MRS, and 3MS. We placed each participant into 1 of 4 categories: dead, severely impaired, mildly or moderately impaired (but still able to function independently), and normal. We further dichotomized each category into unfavorable and favorable medical outcomes, according to predetermined cut points. Scoring in the unfavorable category on any of the 4 scales placed that participant in the unfavorable category overall.

\section{Conduct of the Study}

The first participant was enrolled in September 2003 and the last was enrolled in September 2006. Because of slow accrual and other factors, the study was terminated in December 2006 at the recommendation of the data and safety monitoring board.

\section{Results}

\section{Patient Disposition}

A total of 242 patients were screened, but only 64 (26\%) met the entry criteria. We did not tabulate reasons for study exclusion. Two potential participants were withdrawn before randomization. Thus, we randomized 37 patients to Omr-IgG-am, 12 to Polygam, and 13 to NS (Figure). Thirty-three of the patients in the Omr-IgG-am group, 11 in the Polygam group, and 11 in the NS group were available for follow-up at day 90 . Of the 62 patients randomized, 11 terminated prematurely, 8 because of death (mortality rate $12.9 \%)$. Three $(42.9 \%)$ of the 7 participants who did not have laboratory evidence of acute WNV infection died.

\section{Study Population}

Most of the patients were Caucasian (73\%) and male $(66 \%)$; mean age was 56 years (Table 1). We noted no baseline differences among any of the 3 randomization groups. Diagnosis of acute WNV infection was serologically confirmed in 55 patients; only 3 were positive for WNV by blood PCR. Most participants already carried a laboratory-confirmed diagnosis of WNV infection at the time of referral to the study.

\section{Clinical Characteristics}

Because we found no differences among any of the 3 randomization groups, we summarized the clinical characterization for all 55 patients with confirmed WNV infection. The most common symptoms were fever $>38^{\circ} \mathrm{C}(80 \%)$, chills/rigors (75\%), headache (78\%), nuchal rigidity (47\%), photophobia (33\%), myalgia (78\%), arthralgia (33\%), nausea $(76 \%)$, vomiting $(60 \%)$, diarrhea $(46 \%)$, shortness of breath (24\%), and rash (27\%). Detailed descriptions of the neurologic findings in this study cohort were published previously (23). Of the 44 participants with abnormal CSF findings at initial evaluation, median values were protein $90 \mathrm{mg} / \mathrm{dL}$, glucose $62 \mathrm{mg} / \mathrm{dL}$, erythrocytes 10 cells $/ \mathrm{mm}^{3}$, and leukocytes 96 cells $/ \mathrm{mm}^{3}$ (lymphocytes 62\%, neutrophils $38 \%$ ).

\section{Safety and Tolerability}

As expected for this population of seriously ill patients, large numbers of adverse events (AEs) were recorded (Table 2).

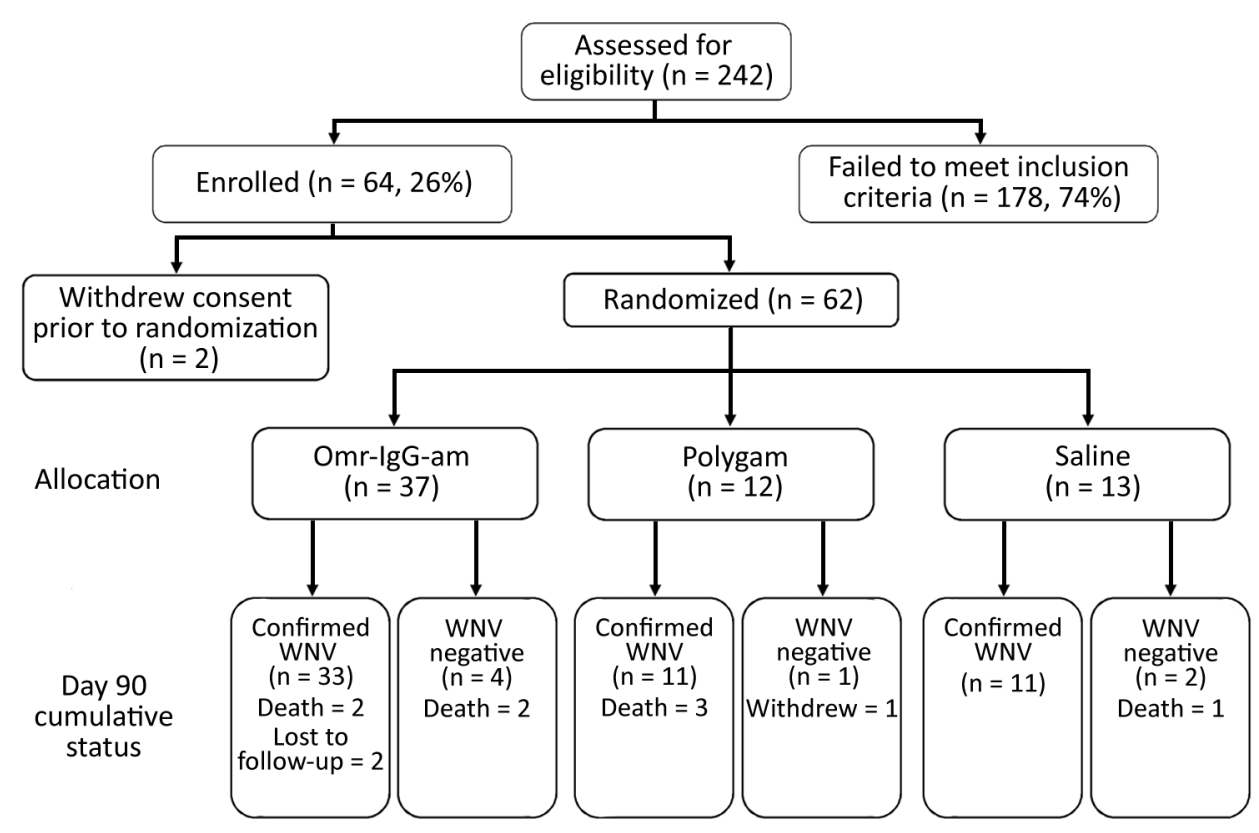

Figure. Patient enrollment, allocation, and final status in study of treatments for West Nile virus central nervous system disease. 
Table 1. Demographics and clinical characteristics of patients in study of treatments for West Nile virus central nervous system disease, by treatment arm*

\begin{tabular}{|c|c|c|c|c|}
\hline Characteristic & Omr-lgG-am, $n=37$ & Polygam, $n=12$ & Normal saline, $\mathrm{n}=13$ & Total, $\mathrm{n}=62$ \\
\hline \multicolumn{5}{|l|}{ Race } \\
\hline Caucasian/not Hispanic & $24(64.9)$ & $10(83.3)$ & $11(84.6)$ & $45(72.6)$ \\
\hline Black/not Hispanic & $2(5.4)$ & 0 & $1(7.7)$ & $3(4.8)$ \\
\hline Hispanic & $8(21.6)$ & $1(8.3)$ & $1(7.7)$ & $10(16.1)$ \\
\hline Other & $3(8.1)$ & $1(8.3)$ & $0(0)^{\prime}$ & $4(6.5)$ \\
\hline \multicolumn{5}{|l|}{ Sex } \\
\hline M & $25(67.6)$ & $7(58.3)$ & $9(69.2)$ & $41(66.1)$ \\
\hline $\mathrm{F}$ & $12(32.4)$ & $5(41.7)$ & $4(30.8)$ & $21(33.9)$ \\
\hline Age, $y$, mean \pm SE & $56.2 \pm 2.2$ & $54.0 \pm 4.1$ & $58.4 \pm 4.8$ & $56.2 \pm 1.8$ \\
\hline \multicolumn{5}{|l|}{ Cerebrospinal fluid } \\
\hline Leukocytes, cells $/ \mu \mathrm{L}$, mean $\pm \mathrm{SE}$ (median) & $207.7 \pm 40.3(124)$ & $187.4 \pm 105.5(58)$ & $146.6 \pm 85.8(37)$ & $192.3 \pm 35.3(95.5)$ \\
\hline$\%$ Lymphocytes, mean \pm SE (median) & $53.9 \pm 5.0(52.5)$ & $39.3 \pm 10.0(36.5)$ & $50.2 \pm 11.6(34)$ & $50.1 \pm 4.3(43)$ \\
\hline $\begin{array}{l}\text { Time from admission to drug infusion, } d \text {, } \\
\text { mean } \pm \text { SE (median) }\end{array}$ & $2.9 \pm 0.5(2)$ & $2.8 \pm 0.5(2.5)$ & $2.0 \pm 0.4(2)$ & $2.7 \pm 0.3(2)$ \\
\hline \multicolumn{5}{|l|}{ Disease group and risk factors } \\
\hline With encephalitis/myelitis & $25(64.7)$ & $9(75.0)$ & $11(84.6)$ & $44(71.0)$ \\
\hline Without encephalitis/myelitis & $12(32.4)$ & $3(25.0)$ & $2(15.4)$ & $17(27.4)$ \\
\hline Hematologic malignancy & $1(8.3)$ & 0 & 0 & $1(5.9)$ \\
\hline Diabetes mellitus & $2(16.7)$ & 0 & 0 & $2(11.8)$ \\
\hline Bone marrow transplant & $1(8.3)$ & 0 & 0 & $1(5.9)$ \\
\hline Immunosuppressive medications & $1(8.3)$ & 0 & 0 & $1(5.9)$ \\
\hline
\end{tabular}

A total of 738 AEs were reported for 58 participants (12.72 AEs/person). The most commonly reported treatmentrelated $\mathrm{AE}$ was hypertension occurring during infusion of the test drug (Table 3). Two grade 3-4 laboratory toxicities (both decreased hematocrit) were reported, both occurring in $\mathrm{Omr}-\mathrm{IgG}$-am recipients.

Safety was defined by the total number of SAEs among the 62 randomized participants, regardless of relatedness to study drug administration. Overall, 29 participants (46.8\%) experienced 63 SAEs (29 with Omr-IgG-am, 25 with Polygam, 9 with NS; Table 4). The estimated SAE rates (with 2 -sided $95 \%$ confidence intervals) were $51.4 \%$ (range $35.3 \%-67.7 \%$ ) for recipients of Omr-IgG-am, $58.3 \%$ (range $30.4 \%-86.2 \%$ ) for recipients of Polygam, and $23.1 \%$ (range $0.2 \%-46.0 \%$ ) for those who received NS. The differences in frequency of SAEs among the 3 treatment groups were not statistically significant. A larger number of neurologic SAEs were reported in the Polygam group (Table 5), although the types of events were highly divergent (declining mental status, quadriparesis, cranial nerve palsies, tremor, seizures) and likely attributable to WNV neuroinvasive disease.

Five SAEs were assessed by the investigator to be possibly, probably, or definitely related to the study medication (Table 4). Two events (chest pain and leukopenia, both assessed as possibly) occurred in Omr-IgG-am recipients; both resolved. One SAE (respiratory distress, assessed as probably) occurred in a Polygam recipient and resolved. Two instances of neutropenia (both assessed as possibly) were reported in NS recipients and resolved.

To monitor the possibility of transmission of other viral pathogens by the immunoglobulin preparations, participants

Table 2. Summary of AEs in intent-to-treat population of patients in study of treatments for West Nile virus central nervous system disease, by treatment arm*

\begin{tabular}{|c|c|c|c|c|}
\hline Characteristic & Omr-IgG-am, n = 37 & Polygam, $n=12$ & Normal saline, $n=13$ & Total, $\mathrm{n}=62$ \\
\hline AEs & 514 & 106 & 118 & 738 \\
\hline patients with an $\mathrm{AE}$ & $36(97.3)$ & $11(91.7)$ & $58(93.5)$ & $58(93.5)$ \\
\hline AEs per patient & 14.28 & 9.64 & 10.73 & 12.72 \\
\hline \multicolumn{5}{|c|}{ Relationship to treatment $†$} \\
\hline Unrelated & $482(93.8)$ & $99(93.4)$ & $113(95.8)$ & $694(94)$ \\
\hline Related & $29(5.6)$ & $7(6.6)$ & $5(4.2)$ & $41(5.6)$ \\
\hline Not stated & $3(0.6)$ & 0 & 0 & $3(0.4)$ \\
\hline \multicolumn{5}{|l|}{ Severity of AE† } \\
\hline Mild & $226(44.0)$ & $45(42.5)$ & $61(51.7)$ & $332(45.0)$ \\
\hline Moderate & $221(43.0)$ & $34(32.1)$ & $45(38.1)$ & $300(40.7)$ \\
\hline Severe & $54(10.5)$ & $13(12.3)$ & $9(7.6)$ & $76(10.3)$ \\
\hline Life-threatening & $13(2.5)$ & $14(13.2)$ & $3(2.5)$ & $30(4.1)$ \\
\hline
\end{tabular}


were screened preinfusion and on day 30 . No participant was positive for HBV or HIV. Two patients (1 recipient of Omr-IgG-am, 1 recipient of Polygam) had negative parvovirus $\mathrm{B} 19 \mathrm{IgG}$ titers preinfusion but had detectable antibodies at follow-up; both of these patients had negative parvovirus IgM titers and PCR assays. This finding likely represents antibody passively acquired from the immunoglobulin infusion rather than acute parvovirus infection. One patient tested positive for hepatitis $\mathrm{C}$ virus by both serologic testing and PCR preinfusion and remained positive on day 90 .

\section{Efficacy}

For each test instrument (BI, 3MS, GOS, and MRS), composite scores measured at the time of enrollment indicated impaired neuropsychological function, which improved over 90 days of follow-up, consistent with the natural history of resolving WNV neurologic disease (Table 6). No significant differences in outcomes were apparent for the 3 treatment groups; therefore, summary statistics allow assessment of day 90 outcomes for the combined population. By $3 \mathrm{MS}, 50.9 \%$ of patients were determined to be normal/unimpaired, $18.2 \%$ had mild or moderate impairment, $12.7 \%$ were severely impaired, and $9.1 \%$ died. When the BI, GOS, and MRS tests were applied to the same population, the percentage of patients who were evaluated as normal/unimpaired were $47.3 \%$ by BI, $36.4 \%$ by GOS, and $14.5 \%$ by MRS; the proportion classified as severely impaired was $27 \%-29 \%$ by each of these 3 instruments.

We further dichotomized outcomes into favorable and unfavorable (Table 7). We found no significant differences in the proportion of patients experiencing an unfavorable outcome at day 90 between treatment and control (although there was again a nonsignificant trend toward better outcomes in the NS group). Overall, $51 \%$ of patients had a favorable outcome. We determined the proportion of
Table 3. Most commonly reported treatment-related adverse events in intent-to-treat population in study of treatments for West Nile virus central nervous system disease, by treatment arm*

\begin{tabular}{lcccc}
\hline & Omr-lgG-am, & Polygam, \\
$\mathrm{n}=37$ & $\begin{array}{c}\text { Normal } \\
\text { sdverse event }\end{array}$ & $\begin{array}{c}\text { saline, } \\
\mathrm{n}=13\end{array}$ & $\begin{array}{c}\text { Total, } \\
\mathrm{n}=62\end{array}$ \\
\hline Hypertension & 7 & 0 & 2 & 9 \\
Dosing error & 6 & 0 & 2 & 8 \\
$\begin{array}{l}\text { Elevated } \\
\text { transaminases }\end{array}$ & 3 & 1 & 0 & 4 \\
Fever, chills & 3 & 1 & 0 & 4 \\
Shortness of breath & 0 & 3 & 0 & 3 \\
Rash, pruritus & 2 & 0 & 0 & 2 \\
Chest pain & 2 & 0 & 0 & 2 \\
Other & 6 & 2 & 1 & 9 \\
\hline Total & 29 & 7 & 5 & 41 \\
\hline${ }^{*}$ Values are no. patients. & & & & \\
\hline
\end{tabular}

patients returning to preillness baseline at day 90 for each randomization group. By the $\mathrm{BI}$ and the MRS, the 2 most sensitive indices, $45.9 \%$ and $32.8 \%$ of patients returned to their preillness status, respectively.

The median duration of hospital stay was 10 days for the Omr-IgG-am group, 12 days for the Polygam group, and 8.5 days for the NS group. Of the 62 patients enrolled in the study, $23(37 \%)$ required intensive care unit (ICU) management. We found no differences in the duration of ICU stay (median 13 days) among the 3 treatment groups. Six patients required mechanical ventilation (median duration 5 days).

\section{Virologic Studies}

All 55 patients initially had positive WNV IgM serologic test results; $36(67.9 \%)$ of 53 patients were WNV IgG positive preinfusion. Reverse transcription PCR for WNV RNA in blood was positive for only $3(5.9 \%)$ of 51 patients before infusion of study medication; no patient had a positive WNV PCR result from blood on day 3. Of the 49 patients for whom day 90 serologic data were available, 40 (81.6\%) were persistently positive for WNV IgM and 47 $(95.9 \%)$ for WNV IgG.

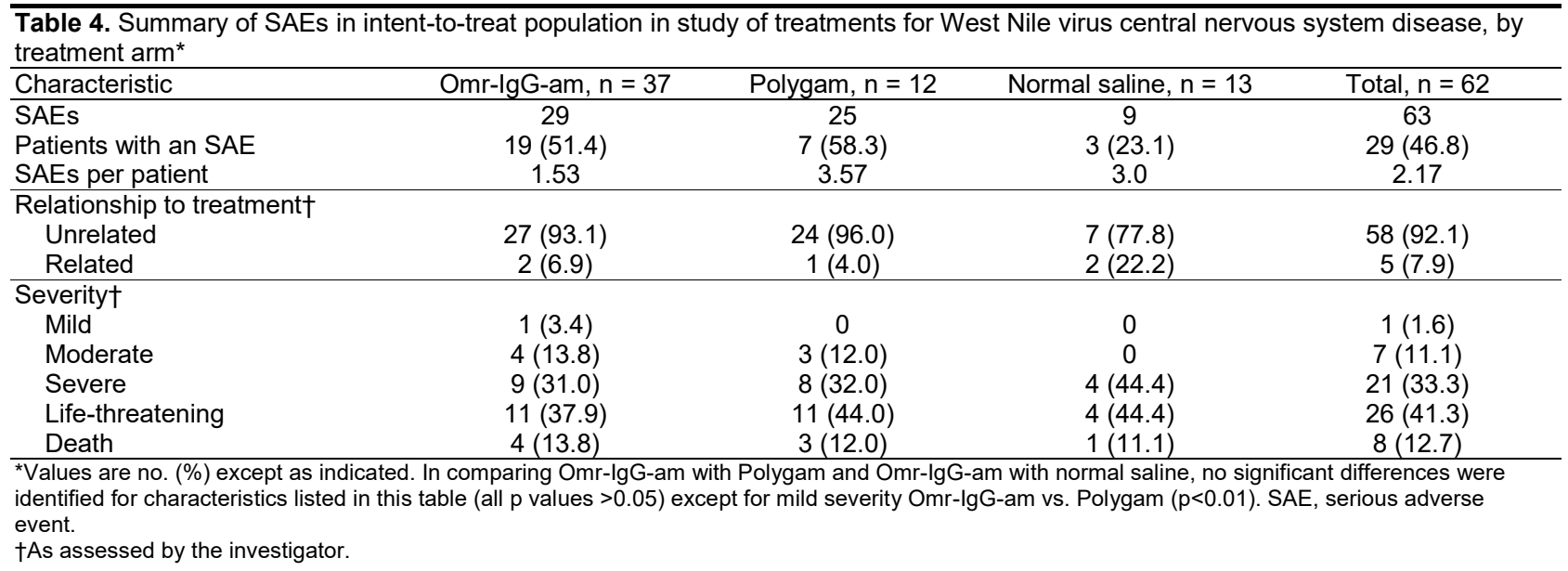


Table 5. Most commonly reported serious adverse events in intent-to-treat population in study of treatments for West Nile virus central nervous system disease, by treatment arm*

\begin{tabular}{|c|c|c|c|c|}
\hline Serious adverse event & Omr-lgG-am, $n=37$ & Polygam, $n=12$ & Normal saline, $n=13$ & Total, $\mathrm{n}=62$ \\
\hline Respiratory failure & 8 & 7 & 2 & 17 \\
\hline Neurologic event or mental status decline & 1 & 11 & 1 & 13 \\
\hline Cardiac event & 4 & 1 & 0 & 5 \\
\hline Anemia & 2 & 1 & 0 & 3 \\
\hline Leukopenia & 1 & 0 & 2 & 3 \\
\hline Urinary tract infection & 1 & 0 & 1 & 2 \\
\hline Pneumonia & 2 & 0 & 0 & 2 \\
\hline Pulmonary embolism & 1 & 0 & 1 & 2 \\
\hline Atelectasis & 0 & 2 & 0 & 2 \\
\hline Pleural effusion & 0 & 1 & 1 & 2 \\
\hline Other & 9 & 2 & 1 & 12 \\
\hline Total & 29 & 25 & 9 & 63 \\
\hline
\end{tabular}

\section{Discussion}

Because preliminary data from animal models and case reports suggested that immunotherapy could alter the outcome of WNV neurologic infection, the National Institute of Allergy and Infectious Diseases Collaborative Antiviral Study Group initiated a clinical study to determine the safety and potential efficacy of a high-titered immunoglobulin product in patients with WNV neuroinvasive disease. The trial was terminated prematurely because of slow accrual and reduced availability of study products. At the time of study termination in 2006, the Polygam supply derived from US sources contained measurable titers of WNV IgG and was no longer an acceptable control.

Looking at recorded SAEs, deaths, and laboratory parameters, we found no differences in safety and tolerability among Omr-IgG-am (0.5 g/kg), Polygam, and NS. Illness outcomes, measured by a panel of 4 neuropsychological test instruments, were not statistically different among the 3 groups. Although the results did not meet statistical significance (in part because of the small sample size), we found a persistent trend toward better outcomes (both illness and death) in the NS group compared with the immunoglobulin groups (Tables 6, 7). Although the validity of this observation is unconfirmed, we do not recommend the administration of immunoglobulin products to patients with neuroinvasive WNV disease until further research can be conducted to establish the relative risk-benefit profile.

The study protocol was designed to capture patients as early as possible in their clinical courses, when immunotherapy was most likely to be beneficial. Unfortunately,

\begin{tabular}{|c|c|c|c|c|}
\hline Instrument & $\begin{array}{c}\text { Omr-lgG-am, } \\
n=33\end{array}$ & $\begin{array}{c}\text { Polygam, } \\
n=11\end{array}$ & $\begin{array}{c}\text { Normal saline, } \\
n=11\end{array}$ & Total, $\mathrm{n}=55$ \\
\hline \multicolumn{5}{|l|}{ Modified Mini-Mental Status Examination } \\
\hline Normal, score $>88$ & $14(42.4)$ & $6(54.5)$ & $8(72.7)$ & $28(50.9)$ \\
\hline Mild/moderately impaired but independent, score 78-88 & $8(24.2)$ & 0 & $2(18.2)$ & $10(18.2)$ \\
\hline Severely impaired, score $<78$ & $5(15.2)$ & $1(9.1)$ & $1(9.1)$ & $7(12.7)$ \\
\hline Dead, score 0 & $2(6.0)$ & $3(27.3)$ & 0 & $5(9.1)$ \\
\hline Not done/lost to follow-up & $4(12.1)$ & $1(9.0)$ & 0 & $5(9.1)$ \\
\hline \multicolumn{5}{|l|}{ Barthel Index } \\
\hline Normal, score >94 & $15(45.5)$ & $5(45.5)$ & $6(54.5)$ & $26(47.3)$ \\
\hline Mild/moderately impaired but independent, score 90-94 & $1(3.0)$ & 0 & $2(18.2)$ & $3(5.5)$ \\
\hline Severely impaired, score $<90$ & $11(33.3)$ & $2(18.2)$ & $3(27.3)$ & $16(29.1)$ \\
\hline Dead, score 0 & $2(6.1)$ & $3(27.3)$ & 0 & $5(9.1)$ \\
\hline Not done/lost to follow-up & $4(12.1)$ & $1(9.0)^{\prime}$ & 0 & $5(9.1)$ \\
\hline \multicolumn{5}{|l|}{ Glasgow Outcome Score } \\
\hline Normal, score 5 & $10(30.3)$ & $3(27.3)$ & $7(63.6)$ & $20(36.4)$ \\
\hline Mild/moderately impaired but independent, score 4 & $9(27.2)$ & $2(18.2)$ & $1(9.1)$ & $12(21.8)$ \\
\hline Severely impaired, score $2-3$ & $9(27.2)$ & $3(27.3)$ & $3(27.3)$ & $15(27.3)$ \\
\hline Dead, score 1 & $2(6.0)$ & $3(27.3)$ & 0 & $5(9.1)$ \\
\hline Not done/lost to follow-up & $3(9.0)$ & 0 & 0 & $3(5.5)$ \\
\hline \multicolumn{5}{|l|}{ Modified Rankin Scale } \\
\hline Normal, score 0 & $4(12.1)$ & 0 & $4(36.4)$ & $8(14.5)$ \\
\hline Mild/moderately impaired but independent, score 1-3 & $15(45.5)$ & $5(45.5)$ & $4(36.4)$ & $24(43.6)$ \\
\hline Severely impaired, score 4-5 & $10(30.3)$ & $3(27.3)$ & $3(27.3)$ & $16(29.1)$ \\
\hline Dead, score 6 & $2(6.0)$ & $3(27.3)$ & 0 & $5(9.1)$ \\
\hline Not done & $2(6.0)$ & 0 & 0 & $2(3.6)$ \\
\hline
\end{tabular}

*Values are no. (\%) patients. In comparing Omr-IgG-am with Polygam and Omr-IgG-am with normal saline, we found no significant differences with respect to the impairment and death categories (excluding "not done") for all instruments listed on this table ( $p>0.05$ for all values). 
High-Titered Immunoglobulin for West Nile Virus

Table 7. Summary of unfavorable outcomes at day 90 after randomization of patients with confirmed West Nile virus in study of treatments for West Nile virus central nervous system disease*

\begin{tabular}{|c|c|c|c|c|}
\hline \multirow[b]{2}{*}{ Regimen } & \multicolumn{3}{|c|}{ No. (\%) patients } & \multirow[b]{2}{*}{ Odds ratio $(95 \% \mathrm{Cl})$} \\
\hline & Favorable & Unfavorable & Missing & \\
\hline Omr-lgG-am, $n=33$ & $15(45.5)$ & $17(51.5)$ & $1(3.0)$ & Referent \\
\hline Polygam, $n=11$ & $5(45.5)$ & $6(54.5)$ & 0 & $1.012(0.198-4.975)$ \\
\hline Normal saline, $\mathrm{n}=11$ & $8(72.7)$ & $3(27.3)$ & 0 & $3.238(0.606-21.959)$ \\
\hline Total confirmed, $\mathrm{n}=55$ & $28(50.9)$ & $26(47.2)$ & $1(1.8)$ & \\
\hline \multicolumn{5}{|c|}{$\begin{array}{l}\text { *Favorable/unfavorable determinations made on the basis of results of } 4 \text { standardized assessments of cognitive and functional status: Barthel Index } \\
\text { (favorable } \geq 90 \text {, unfavorable }<90 \text { ), Modified Rankin Scale (favorable } 0-3 \text {, unfavorable } 4-6 \text { ), Glasgow Outcome Score (favorable } 4 \text { or } 5 \text {, unfavorable }<4 \text { ), } \\
\text { and the Modified Mini Mental State Examination (favorable } \geq 78 \text {, unfavorable }<78 \text { ). }\end{array}$} \\
\hline
\end{tabular}

patients often entered the study pool later, after a diagnosis of WNV infection had been confirmed by laboratory testing. Delays in enrollment and study drug administration could have diminished the potential efficacy of OmrIgG-am. By the time symptomatic neurologic disease was present, the infection had probably progressed to a point at which the administration of passive immunotherapy was unlikely to be beneficial.

In this study population of relatively healthy middle-aged persons, $15 \%$ (as assessed by MRS) to $50 \%$ (as assessed by $\mathrm{BI})$ returned to baseline function. Only $33 \%-46 \%$ of patients returned to their preillness state (as defined retrospectively by a family member). These data differ somewhat from proportions of patients experiencing normal or mild to moderate impairment reported by other investigators (24-28). Other published WNV case series had different demographic and disease characteristics and used different definitions, making interstudy comparisons problematic. Our population had a relatively high percentage of patients requiring ICU care and extended durations of hospitalization.

Effective therapy for WNV neuroinvasive disease remains an unmet medical need. A human monoclonal antibody directed against WNV has shown activity in animal models $(29,30)$ but remains unproven for human infection $(31,32)$. Antiviral drugs that can be initiated early in the course of WNV disease are urgently needed (33-35).

We learned several lessons that will inform the design of future studies of therapies for WNV disease. At various time points, this clinical trial activated 71 individual sites in 28 US states and 3 Canada provinces but was still unable to achieve full enrollment. The challenges encountered during the conduct of the study were numerous. First, and most notably, the precise geographic localization of emerging vectorborne illnesses is difficult to predict. WNV infection occurs seasonally (usually July-October in North America) and in scattered geographic locations. We worked closely with our collaborators at $\mathrm{CDC}$ but were unable to project with sufficient precision where the incidence of WNV disease would be highest in the subsequent season. Even when we correctly predicted geographic regions where disease activity was high, it was extremely difficult to activate sufficient study sites quickly. Furthermore, WNV infection is predominantly a rural disease, whereas many of our study sites were located in urban areas. Second, it was often difficult to refer potential participants to active study sites. Investigators received numerous calls regarding WNV patients who were hospitalized at nonparticipating medical centers, some even in the same city. However, logistical and financial constraints prevented most of these patients from being transferred to a site with an IRB-approved protocol in place. Third, most patients were considered for enrollment in the study only after WNV infection had been confirmed. The study was designed to enable enrollment of suspected WNV patients (before laboratory confirmation) to expedite early therapy, but this rarely occurred, as demonstrated by the mean time from admission to study drug administration (2.6 days). Animal model data have indicated that passive immunotherapy of WNV infection with exogenous antibodies is most effective if instituted very early in the course of infection.

Finally, there were regulatory constraints, as we have described previously (36). The median time required to obtain IRB approval at US medical centers was $\approx 6$ months (36). Consequently, many potential participants could not be enrolled because sites failed to receive IRB approval and activate the protocol in a timely manner. The availability of a central IRB could have shortened site registration time considerably and potentially enhanced patient enrollment. As a result of unpredictable geographic variation, fluctuating incidence, and seasonal enrollment windows, an agile and flexible universal IRB system will be mandatory if future largescale clinical trials of therapies for emerging vectorborne infectious diseases (e.g., WNV, Chikungunya, dengue, Zika virus) are to be successfully performed in the United States.

\section{Acknowledgments}

The authors thank James Sejvar, Lyle Petersen, and Robert Lanciotti of the Centers for Disease Control and Prevention for invaluable discussions regarding the epidemiology and diagnosis of WNV infection. A list of investigators and coordinators who enrolled participants in this study is provided in the Appendix (http://wwwnc.cdc.gov/EID/article/25/11/19-0537-App1.pdf).

The work was supported by a contract from the National Institutes of Health (NIH), National Institute of Allergy and Infectious Diseases (N01A130025; Richard J. Whitley, MD, principal investigator). The study drug was provided by OMRIX Biopharmaceuticals, Ltd. (Tel Aviv, Israel). 


\section{About the Author}

Dr. Gnann is a professor of medicine in the Division of Infectious

Diseases at the Medical University of South Carolina. He is an infectious diseases specialist with interest in clinical virology.

\section{References}

1. Watson JT, Pertel PE, Jones RC, Siston AM, Paul WS, Austin CC, et al. Clinical characteristics and functional outcomes of West Nile fever. Ann Intern Med. 2004;141:360-5. https://doi.org/10.7326/0003-4819-141-5-200409070-00010

2. Campbell GL, Marfin AA, Lanciotti RS, Gubler DJ. West Nile virus. Lancet Infect Dis. 2002;2:519-29. https://doi.org/10.1016/ S1473-3099(02)00368-7

3. Hayes EB, Gubler DJ. West Nile virus: epidemiology and clinical features of an emerging epidemic in the United States. Annu Rev Med. 2006;57:181-94. https://doi.org/10.1146/ annurev.med.57.121304.131418

4. O'Leary DR, Marfin AA, Montgomery SP, Kipp AM, Lehman JA, Biggerstaff BJ, et al. The epidemic of West Nile virus in the United States, 2002. Vector Borne Zoonotic Dis. 2004;4:61-70. https://doi.org/10.1089/153036604773083004

5. Petersen LR, Brault AC, Nasci RS. West Nile virus: review of the literature. JAMA. 2013;310:308-15. https://doi.org/10.1001/ jama.2013.8042

6. Yeung MW, Shing E, Nelder M, Sander B. Epidemiologic and clinical parameters of West Nile virus infections in humans: a scoping review. BMC Infect Dis. 2017;17:609. https://doi.org/ 10.1186/s12879-017-2637-9

7. Roehrig JT. West nile virus in the United States - a historical perspective. Viruses. 2013;5:3088-108. https://doi.org/10.3390/ v5123088

8. Centers for Disease Control and Prevention. Final cumulative maps and data for 1999-2017. 2018 [cited 2018 Nov 13]. https://www.cdc.gov/westnile/statsmaps/cumMapsData.html

9. Sejvar JJ, Lindsey NP, Campbell GL. Primary causes of death in reported cases of fatal West Nile fever, United States, 2002-2006. Vector Borne Zoonotic Dis. 2011;11:161-4. https://doi.org/10.1089/vbz.2009.0086

10. Lindsey NP, Staples JE, Lehman JA, Fischer M. Surveillance for human West Nile virus disease_-United States, 1999-2008. MMWR Surveill Summ. 2010;59:1-17.

11. Petersen LR, Carson PJ, Biggerstaff BJ, Custer B, Borchardt SM, Busch MP. Estimated cumulative incidence of West Nile virus infection in US adults, 1999-2010. Epidemiol Infect. 2013; 141:591-5. https://doi.org/10.1017/S0950268812001070

12. Ben-Nathan D, Lustig S, Tam G, Robinzon S, Segal S, Rager-Zisman B. Prophylactic and therapeutic efficacy of human intravenous immunoglobulin in treating West Nile virus infection in mice. J Infect Dis. 2003;188:5-12. https://doi.org/ $10.1086 / 376870$

13. Haley M, Retter AS, Fowler D, Gea-Banacloche J, O'Grady NP. The role for intravenous immunoglobulin in the treatment of West Nile virus encephalitis. Clin Infect Dis. 2003;37:e88-90. https://doi.org/10.1086/377172

14. Hamdan A, Green P, Mendelson E, Kramer MR, Pitlik S, Weinberger M. Possible benefit of intravenous immunoglobulin therapy in a lung transplant recipient with West Nile virus encephalitis. Transpl Infect Dis. 2002;4:160-2.

15. Shimoni Z, Niven MJ, Pitlick S, Bulvik S. Treatment of West Nile virus encephalitis with intravenous immunoglobulin. Emerg Infect Dis. 2001;7:759. https://doi.org/10.3201/eid0704.017432

16. Ben-Nathan D, Gershoni-Yahalom O, Samina I, Khinich Y, Nur I, Laub O, et al. Using high titer West Nile intravenous immunoglobulin from selected Israeli donors for treatment of West
Nile virus infection. BMC Infect Dis. 2009;9:18

https://doi.org/10.1186/1471-2334-9-18

17. Mahoney FI, Barthel DW. Functional evaluation: the Barthel Index. Md State Med J. 1965;14:61-5.

18. McDowell I, Kristjansson B, Hill GB, Hébert R. Community screening for dementia: the Mini Mental State Exam (MMSE) and Modified Mini-Mental State Exam (3MS) compared. J Clin Epidemiol. 1997;50:377-83. https://doi.org/10.1016/ S0895-4356(97)00060-7

19. Teng EL, Chui HC. The Modified Mini-Mental State (3MS) examination. J Clin Psychiatry. 1987;48:314-8.

20. Martin DA, Noga A, Kosoy O, Johnson AJ, Petersen LR, Lanciotti RS. Evaluation of a diagnostic algorithm using immunoglobulin $\mathrm{M}$ enzyme-linked immunosorbent assay to differentiate human West Nile virus and St. Louis encephalitis virus infections during the 2002 West Nile virus epidemic in the United States. Clin Diagn Lab Immunol. 2004;11:1130-3.

21. Zhang W, Wu J, Li Y, Li F, Njoo H. Rapid and accurate in vitro assays for detection of West Nile virus in blood and tissues. Transfus Med Rev. 2009;23:146-54. https://doi.org/10.1016/ j.tmrv.2008.12.008

22. Tyler KL, Pape J, Goody RJ, Corkill M, Kleinschmidt-DeMasters BK. CSF findings in 250 patients with serologically confirmed West Nile virus meningitis and encephalitis. Neurology. 2006;66:361-5. https://doi.org/10.1212/01.wnl.0000195890.70898.1f

23. Hart J Jr, Tillman G, Kraut MA, Chiang HS, Strain JF, Li Y, et al.; NIAID Collaborative Antiviral Study Group West Nile Virus 210 Protocol Team. West Nile virus neuroinvasive disease: neurological manifestations and prospective longitudinal outcomes. BMC Infect Dis. 2014;14:248. https://doi.org/10.1186/ 1471-2334-14-248

24. Haaland KY, Sadek J, Pergam S, Echevarria LA, Davis LE, Goade D, et al. Mental status after West Nile virus infection. Emerg Infect Dis. 2006;12:1260-2. https://doi.org/10.3201/ eid1708.060097

25. Klee AL, Maidin B, Edwin B, Poshni I, Mostashari F, Fine A, et al. Long-term prognosis for clinical West Nile virus infection. Emerg Infect Dis. 2004;10:1405-11. https://doi.org/10.3201/ eid1008.030879

26. Hughes JM, Wilson ME, Sejvar JJ. The long-term outcomes of human West Nile virus infection. Clin Infect Dis. 2007;44:1617 24. https://doi.org/10.1086/518281

27. Sejvar JJ, Curns AT, Welburg L, Jones JF, Lundgren LM, Capuron L, et al. Neurocognitive and functional outcomes in persons recovering from West Nile virus illness. J Neuropsychol. 2008;2:477-99. https://doi.org/10.1348/174866407X218312

28. Sejvar JJ, Haddad MB, Tierney BC, Campbell GL, Marfin AA, Van Gerpen JA, et al. Neurologic manifestations and outcome of West Nile virus infection. JAMA. 2003;290:511-5. https://doi.org/ 10.1001/jama.290.4.511

29. Morrey JD, Siddharthan V, Olsen AL, Roper GY, Wang H, Baldwin TJ, et al. Humanized monoclonal antibody against West Nile virus envelope protein administered after neuronal infection protects against lethal encephalitis in hamsters. J Infect Dis. 2006;194:1300-8. https://doi.org/10.1086/508293

30. Morrey JD, Siddharthan V, Wang H, Hall JO, Skirpstunas RT, Olsen AL, et al. West Nile virus-induced acute flaccid paralysis is prevented by monoclonal antibody treatment when administered after infection of spinal cord neurons. J Neurovirol. 2008;14:15263. https://doi.org/10.1080/13550280801958930

31. Oliphant T, Engle M, Nybakken GE, Doane C, Johnson S, Huang L, et al. Development of a humanized monoclonal antibody with therapeutic potential against West Nile virus. Nat Med. 2005;11:522-30. https://doi.org/10.1038/nm1240

32. Throsby M, Geuijen C, Goudsmit J, Bakker AQ, Korimbocus J, Kramer RA, et al. Isolation and characterization of human 
monoclonal antibodies from individuals infected with West Nile virus. J Virol. 2006;80:6982-92. https://doi.org/10.1128/ JVI.00551-06

33. Diamond MS. Progress on the development of therapeutics against West Nile virus. Antiviral Res. 2009;83:214-27. https://doi.org/10.1016/j.antiviral.2009.05.006

34. Lim SP, Shi PY. West Nile virus drug discovery. Viruses. 2013;5:2977-3006. https://doi.org/10.3390/v5122977

35. Morrey JD, Taro BS, Siddharthan V, Wang H, Smee DF, Christensen AJ, et al. Efficacy of orally administered T-705 pyrazine analog on lethal West Nile virus infection in rodents. Antiviral Res. 2008;80:377-9. https://doi.org/10.1016/ j.antiviral.2008.07.009
36. Jester PM, Tilden SJ, Li Y, Whitley RJ, Sullender WM. Regulatory challenges: lessons from recent West Nile virus trials in the United States. Contemp Clin Trials. 2006;27:254-9. https://doi.org/10.1016/j.cct.2006.02.004

Addresses for correspondence: John W. Gnann, Medical University of South Carolina Department of Medicine, Division of Infectious Diseases, 135 Rutledge Ave, MSC 752, Charleston, SC 29425, USA; email: gnann@musc. edu; Richard J. Whitley, University of Alabama at Birmingham Department of Pediatrics, Division of Infectious Diseases, 1600 7th Ave South, CHB 303P, Birmingham, AL 35233-1711, USA; email: rwhitley@peds.uab.edu

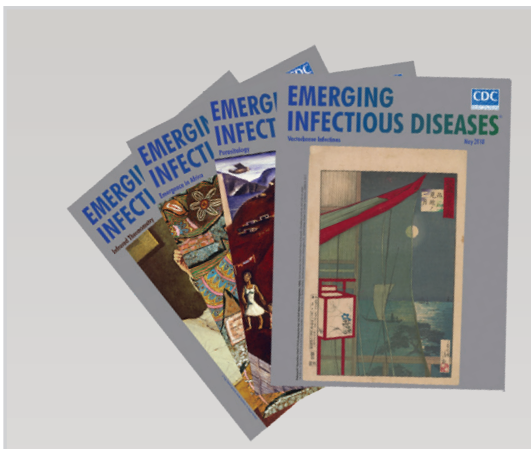

- History of Mosquitoborne Diseases in the United States and Implications for New Pathogens

- Surveillance for Mosquitoborne Transmission of Zika Virus, New York City, NY, USA, 2016

- Two Cases of Israeli Spotted Fever with Purpura Fulminans, Sharon District, Israel

- Antimicrobial Resistance in Invasive Bacterial Infections in Hospitalized Children, Cambodia, 2007-2016

- Epidemic Dynamics of Vibrio parahaemolyticus Illness in a Hotspot of Disease Emergence, Galicia, Spain

- Dynamics of Spirochetemia and Early PCR Detection of Borrelia miyamotoi

- Transmission of Severe Fever with Thrombocytopenia Syndrome Virus by Haemaphysalis longicornis Ticks, China

- Seroprevalence of Severe Fever with Thrombocytopenia Syndrome Virus Antibodies in Rural Areas, South Korea

- Human Usutu Virus Infection with Atypical Neurologic Presentation, Montpellier, France, 2016

- Alkhurma Hemorrhagic Fever Virus RNA in Hyalomma rufipes Ticks Infesting Migratory Birds, Europe and Asia Minor

- Cholera Epidemic in South Sudan and Uganda and Need for International Collaboration in Cholera Control

\section{May 2018}

\section{Vectorborne Infections}

- External Quality Assessment for Zika Virus Molecular Diagnostic Testing, Brazil

- Spread of Plague by Respiratory Droplets or Ectoparasites

- A Mental Models Approach to Assessing Public Understanding of Zika Virus, Guatemala

- Heartland Virus and Hemophagocytic Lymphohistiocytosis in Immunocompromised Patient, Missouri, USA

- Equine Encephalosis Virus in India, 2008 Epizootic Hemorrhagic Disease Virus Serotype 6 Infection in Cattle, Japan, 2015

- Fatal Visceral Leishmaniasis Caused by Leishmania infantum, Lebanon

- Second Human Pegivirus in Hepatitis C Virus-Infected and Hepatitis C Virus/HIV-1-Co-infected Persons Who Inject Drugs, China

- Characterization of Clinical Isolates of Bartonella henselae Strains, South Korea

- Antimicrobial-Resistant Bacteria in Infected Wounds, Ghana, 2014

- Foodborne Outbreaks Caused by Human Norovirus GII.P17-GII.17-Contaminated Nori, Japan, 2017

- Bartonella henselae DNA in Seronegative Patients with CatScratch Disease 